\title{
Impact of Success Cases under RKVY Scheme at Krishi Vigyan Kendra, Rudrur, Nizamabad District, India
}

\author{
C. Padma Veni ${ }^{1}$, Bandaru Venkata Rajkumar ${ }^{2}$, P. Vijay Kumar ${ }^{3}$, M. Bhavya Manjari ${ }^{4}$ \\ and B. Kranthi Kumar ${ }^{5^{*}}$
}

${ }^{1}$ (Agril. Extension) \& Programme Coordinator, ${ }^{2}$ (Horticulture), ${ }^{3}$ (Plant Protection), ${ }^{4}$ (Home Science), 5 (Crop Production), KVK, Rudrur, Telangana, India

*Corresponding author

\section{Keywords \\ Rashtriya Krishi Vikas Yojana (RKVY), Annual growth in agriculture}

Article Info

Accepted:

20 September 2018

Available Online:

10 October 2018

A B S T R A C T

Rashtriya Krishi Vikas Yojana (RKVY) is a State Plan Scheme of Additional Central Assistance launched during August, 2007 as a part of the $11^{\text {th }}$ Five year plan by the Government of India to achieve $4 \%$ annual growth in agriculture through development of agriculture and allied sectors. Krishi Vigyan Kendra, Rudrur was allocated fund Rs.22,00,000/- under RKVY during 2014-15 for organising Field Testing and Popularizing Integrated Farming System Approach for the sustainable livelihoods where Vanaraja Birds were distributed to 37 beneficiaries. Smt. Shameem, SHG member of KVK adopted village successfully implemented backyard poultry and started and rose to the occasion to earn Rs. 2000/- per month by 2016-17 after consuming by the family. KVK motivated the farmers on the use of Raised bed planter, Sugarcane Ridger, Paddy straw Baler to promote Farm mechanization in their fields by use of Success stories documented. The farmers after attending demonstrations at KVK, implemented Raised Bed Planting of Maize, Earthing operations in Sugarcane and Bailing of paddy straw with Paddy Straw Baler.

\section{Introduction}

Rashtriya Krishi Vikas Yojana (RKVY) is a State Plan Scheme of Additional Central Assistance launched during August, 2007 as a part of the $11^{\text {th }}$ Five year plan by the Government of India to achieve $4 \%$ annual growth in agriculture through development of agriculture and allied sectors. Under this scheme KVK, Rudrur distributed Vanaraja 
birds for the promotion of backyard poultry during 2012-13, promoted Extension services like skill development \& trained the farming community and organized study tours of farmers to places of interest to them, especially to Research Institutions etc. and promoted farm mechanization by conducting a series of demonstrations on the farm implements received during 2014-15 viz. 4WD $22 \mathrm{hp}$ Mini tractor with attachments (Tractor mounted Boom sprayer, Cultivator, Sugarcane Ridger, Seed cum ferti drill, Reversible mould board plough, Rotovator, Leveling blade, Tractor trailer, Power tiller, Power tiller trolley), Multipurpose power weeder, Tractor operated multi crop thresher, Paddy straw baler, Raised Bed Planter, Tractor drawn 11 tyre rigid cultivator, Front mounted leveling blade, Sprinkler system, High pressure knapsack sprayer (Taiwan), Paddy drum seeder and Paddy power weeder.

The Impact of few success cases under RKVY scheme is presenting below.

\section{Backyard poultry sustained Shameem livelihood}

Backyard poultry sustained livelihood of Shameem, SHG women of Jalalpur, KVK adopted village, Nizamabad district, Telangana state with an assured income of Rs.27, 500 per annum. Smt. Shameem struggled hard for family income in the absence of even small enterprise up till 201112. With the choose of Jalalpur as a KVK adopted village smt. Shameem has become an interested, enthusiastic and dynamic member of Scientific Advisory Committee (SAC) during 2011-12 and participated in many KVK training programmes since then.

Under RKVY project on "Field Testing and Popularizing Integrated Farming System Approach for the sustainable livelihoods" during 2012-13 Krishi Vigyan Kendra, Rudrur distributed Vanaraja birds to 37 beneficiaries @ 11 hens and 1 cock per beneficiary brought from the Project Directorate on Poultry, Rajendranagar, Hyderabad along with organizing training programmes on Poultry feed and poultry manure for cultivation of field crops, orchards and vegetables. All 37 beneficiaries got benefited and Smt. Shameem as one among them with five family members says, the birds with good weight lay egg for eight months from the age of 6 months and daily consumption of which improves family health and eggs for hatchery promote micro enterprise (Rs. 10/egg). Ten families in Jalalpur village bought eggs from Smt. Shameem and reared vanaraja birds getting an assured income with improved family health. From 2012 till date she produced 30 birds despite the problem of gulping by domestic dogs and cats in her backyard.

\section{Raised bed planter raised maize yields}

Maize (Zea mays) is one of the important cereal crops in Nizamabad district grown as rainfed kharif crop after paddy as the soils and climate are most conducive to the crop. But most often the crop is getting affected with excess rains resulting low yields. To overcome the problem and get high yield, KVK, Rudrur conducted On Farm Testing (OFT) on "Performance Assessment of Raised Bed Planter in Maize" in six locations in Hanmajipet village, Banswada mandal, erstwhile Nizamabad district (Present Kamareddy district) during kharif, 2017.

The farmers practice of sowing the seed on flat beds which got affected with rains received during August and September, 2017 (173.4 and $282.3 \mathrm{~mm}$, respectively) resulted in low yield, whereas the raised beds prepared by Raised Bed Planter helped in preventing waterlogging allowing the soils to drain excess water with the maintenance of good aeration, ultimately yielding good. 


\section{Details of Backyard Poultry of Smt. Shameem}

\begin{tabular}{|l|l|}
\hline 1 & Average body weight of female vanaraja bird at 20 weeks of age $=2150 \mathrm{~g}$ \\
\hline 2 & Average body weight of male vanaraja bird at 20 weeks of age $=2430 \mathrm{~g}$ \\
\hline 3 & Average body weight of female vanaraja bird at 40 weeks of age $=3540 \mathrm{~g}$ \\
\hline 4 & Average body weight of male vanaraja bird at 40 weeks of age $=4903 \mathrm{~g}$ \\
\hline 5 & The average age at first egg laying $=180$ days \\
\hline 6 & The average egg production at the age of 40 weeks $=59$ eggs \\
\hline 7 & The annual egg production per hen $=154$ numbers
\end{tabular}

\section{Details of expenditure on backyard poultry of Smt. Shameem}

\begin{tabular}{|c|c|c|c|c|c|c|}
\hline $\begin{array}{l}\text { S. } \\
\text { No }\end{array}$ & Year & Vanaraja birds & & $\begin{array}{l}\text { Expenditure } \\
\text { incurred on } \\
\text { rearing } \\
\text { vanaraja birds } \\
\text { per annum }\end{array}$ & $\begin{array}{l}\text { Income per annum after } \\
\text { taking } 5 \text { eggs daily for } \\
\text { family consumption }\end{array}$ & $\begin{array}{l}\text { Profit } \\
\text { (Rs.) }\end{array}$ \\
\hline \multirow[t]{2}{*}{1.} & \multirow[t]{2}{*}{$2012-13$} & No. of Vanaraja birds & 11 & \multirow[t]{2}{*}{ Rs. 5,500 } & $6 \times 240$ (8 months $\times 30$ & \multirow[b]{2}{*}{$\begin{array}{l}7200- \\
5500=1,700\end{array}$} \\
\hline & & $\begin{array}{l}\text { No. of eggs produced } \\
\text { per day }\end{array}$ & 11 & & $\begin{array}{l}\text { days })=1440 \text { eggs } \\
\text { after keeping } 50 \% \text { for own } \\
\text { hatchery purpose }=720 \text { eggs } \\
\text { only } \\
\text { - } \quad 720 \times 10 /-=7200.00\end{array}$ & \\
\hline \multirow[t]{5}{*}{2.} & \multirow[t]{5}{*}{ 2016-17 } & No. of Vanaraja birds & 25 & \multirow[t]{5}{*}{ Rs. 10,500} & \multirow{5}{*}{$\begin{array}{l}\text { - } 15 \times 240 \text { ( } 8 \text { months } x \\
30 \text { days }=3600 \text { eggs } \\
\text { - } 50 \% \text { of eggs sold } \\
\text { after keeping } 50 \% \text { for own } \\
\text { hatchery purpose }=1800 \text { eggs } \\
\text { only } \\
\text { - } \quad 1800 \times 20 /-=36000.00 \\
\text { - } \quad 5 \times 400 /-=2000.00\end{array}$} & \multirow{5}{*}{$\begin{array}{l}36,000+ \\
2000- \\
10,500= \\
27,500\end{array}$} \\
\hline & & $\begin{array}{l}\text { No. of eggs produced } \\
\text { per day }\end{array}$ & 25 & & & \\
\hline & & $\begin{array}{l}\text { Average no. of } \\
\text { damaged eggs per day }\end{array}$ & 5 & & & \\
\hline & & $\begin{array}{l}\text { Average no. of healthy } \\
\text { eggs per day }\end{array}$ & 20 & & & \\
\hline & & $\begin{array}{l}\text { No. of birds sold for } \\
\text { meat purpose }\end{array}$ & 5 & & & \\
\hline
\end{tabular}

Smt. Shameem started earning Rs. 1,700 during 2012-13 with 11 birds and rose to the occasion to earn Rs. 27,500 by 2016-17 with backyard poultry.

Table.1 Yield and Economic details of Maize (var. KNMH-4010141) by Raised Bed Planter and Flat Bed method

\begin{tabular}{|l|c|c|}
\hline Particulars & Raised bed Planter sowing & Farmers practice of Flat bed method \\
\hline Yield (q/acre) & 33.58 & 29.00 \\
\hline Gross income (Rs.) & 47856 & 41491 \\
\hline Net Returns (Rs.) & 33756 & 25875 \\
\hline B: C ratio & $3.40: 1$ & $2.66: 1$ \\
\hline
\end{tabular}


Performance of Sugarcane Ridger in comparision to traditional method is given below

\begin{tabular}{|c|c|c|c|}
\hline Particulars & Operation & Spacing & Cost of Cultivation \\
\hline Traditional method & Earthing up & $90 \times 30 \mathrm{~cm}$ & $\begin{array}{l}24 \text { persons for } 2 \text { times @ } \\
\text { Rs. } 410 / \text { - per person } \\
24 \text { persons x } 410 /- \text { x } 2 \\
\text { times }=19680 / \text { - per acre }\end{array}$ \\
\hline $\begin{array}{l}\text { Tractor drawn } \\
\text { Sugarcane Ridger }\end{array}$ & Earthing up & $150 \times 30 \mathrm{~cm}(5 \mathrm{ft})$ & $\begin{array}{l}2 \text { hours per acre }+10 \\
\text { litres fuel charges }\end{array}$ \\
\hline
\end{tabular}

Distribution of Vanaraja birds and organizing Training programmes

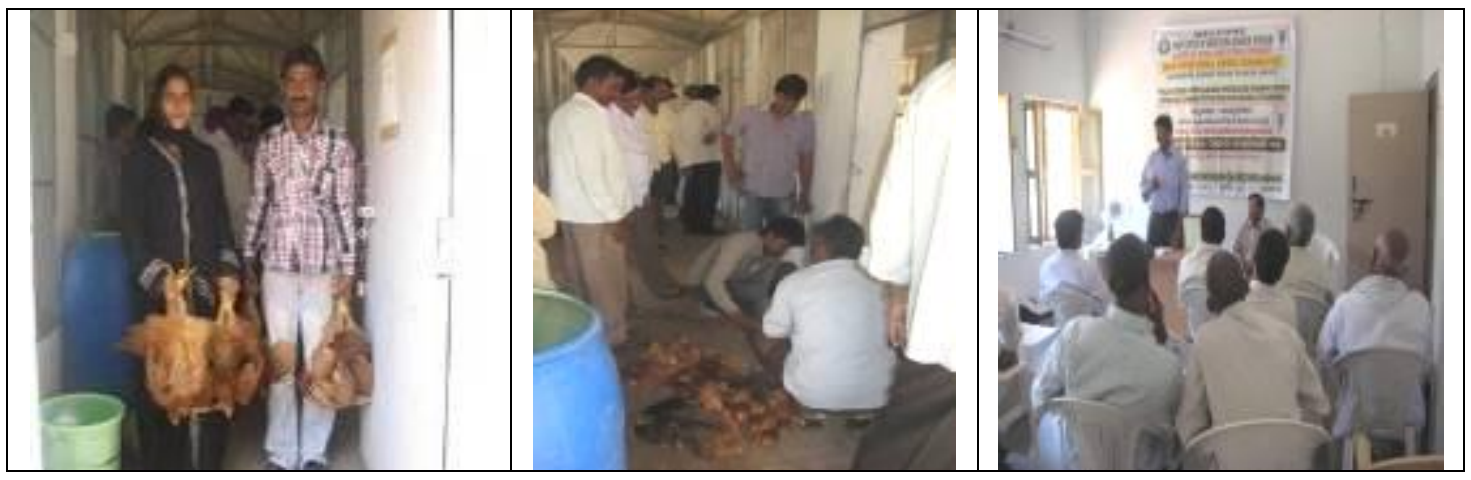

Smt. Shameem with her Poultry enterprise

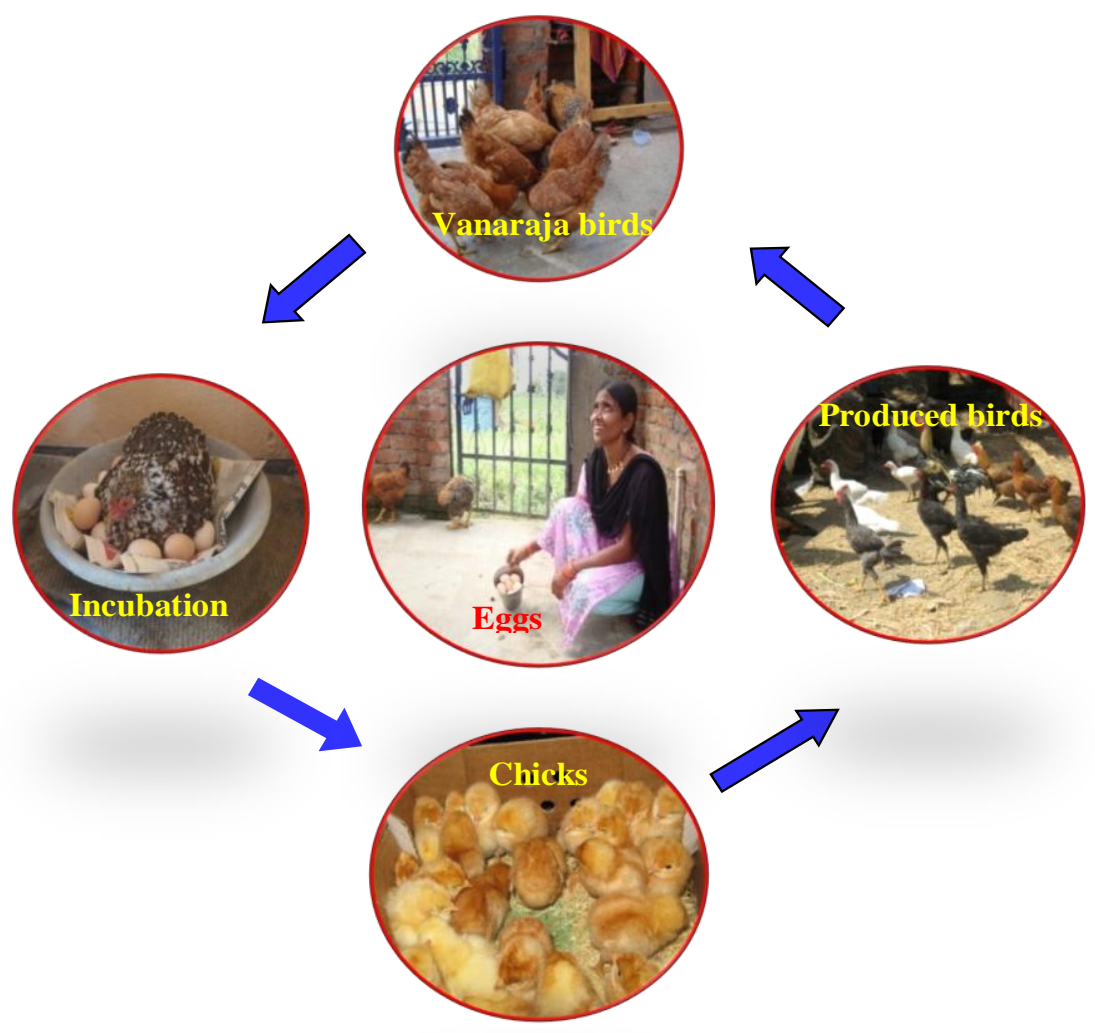




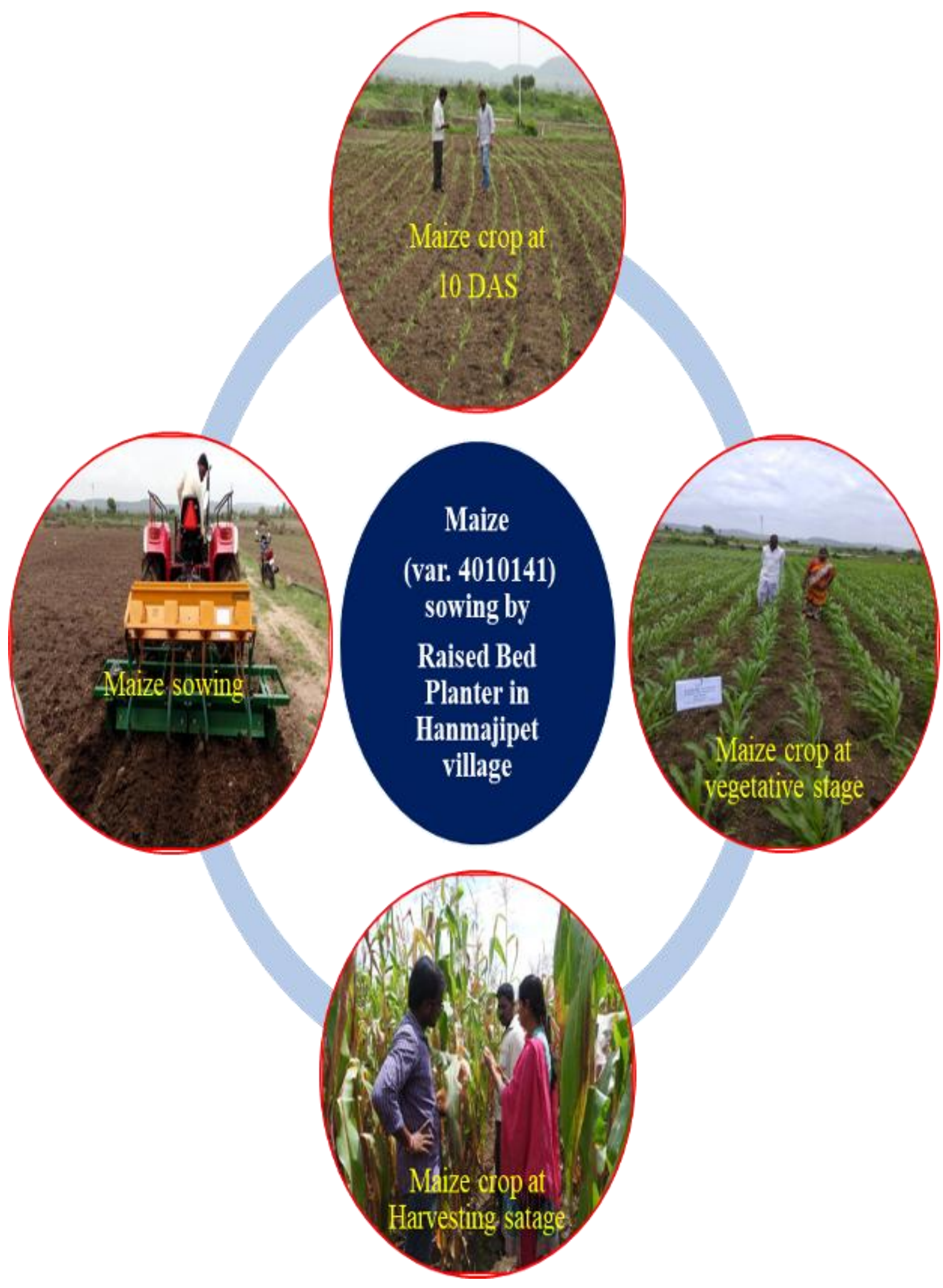


A series of demonstrations on Raised Bed Planter were conducted to the farmers at KVK, Rudrur

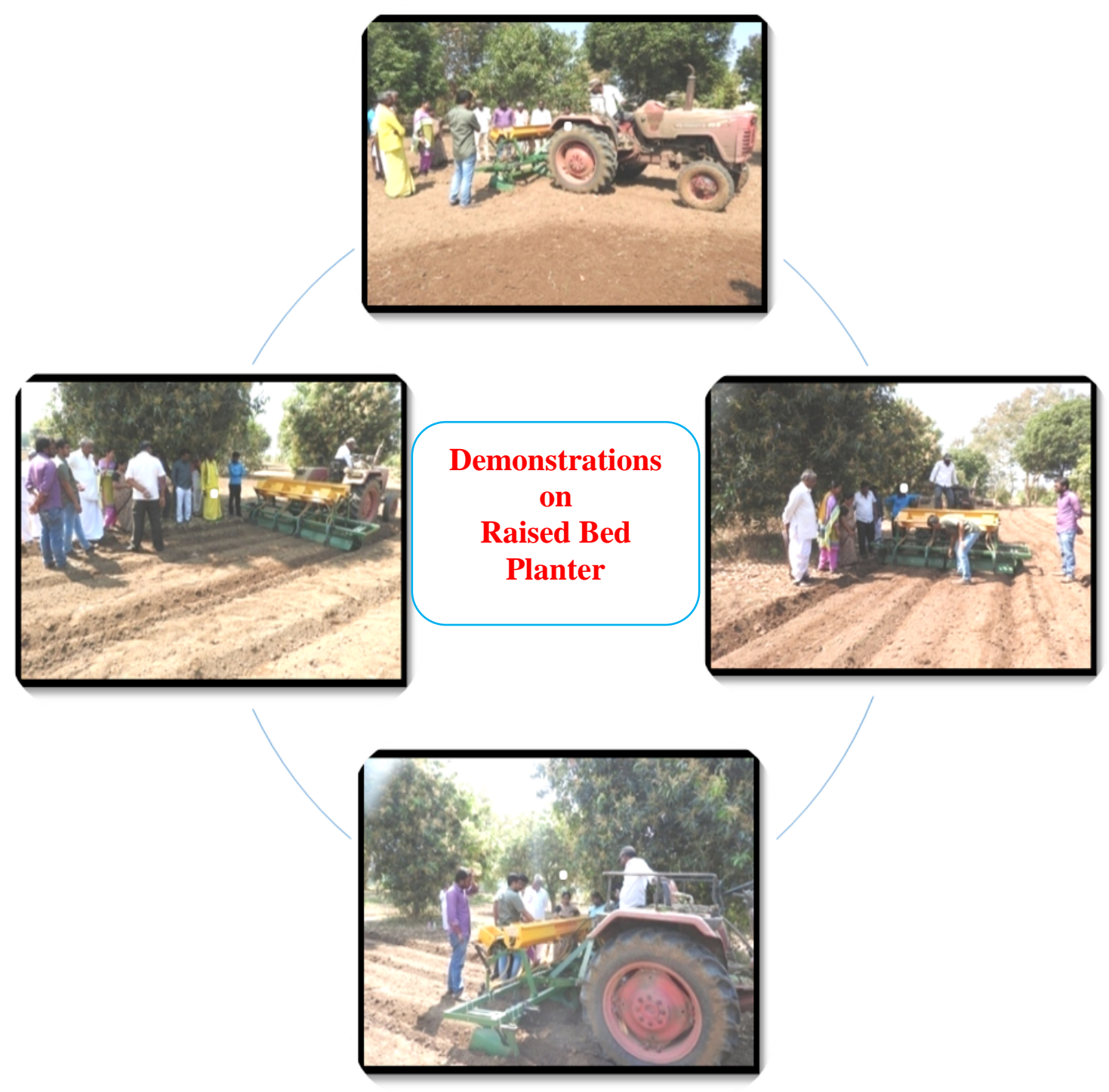

Earthing up operation by Sugarcane Ridger
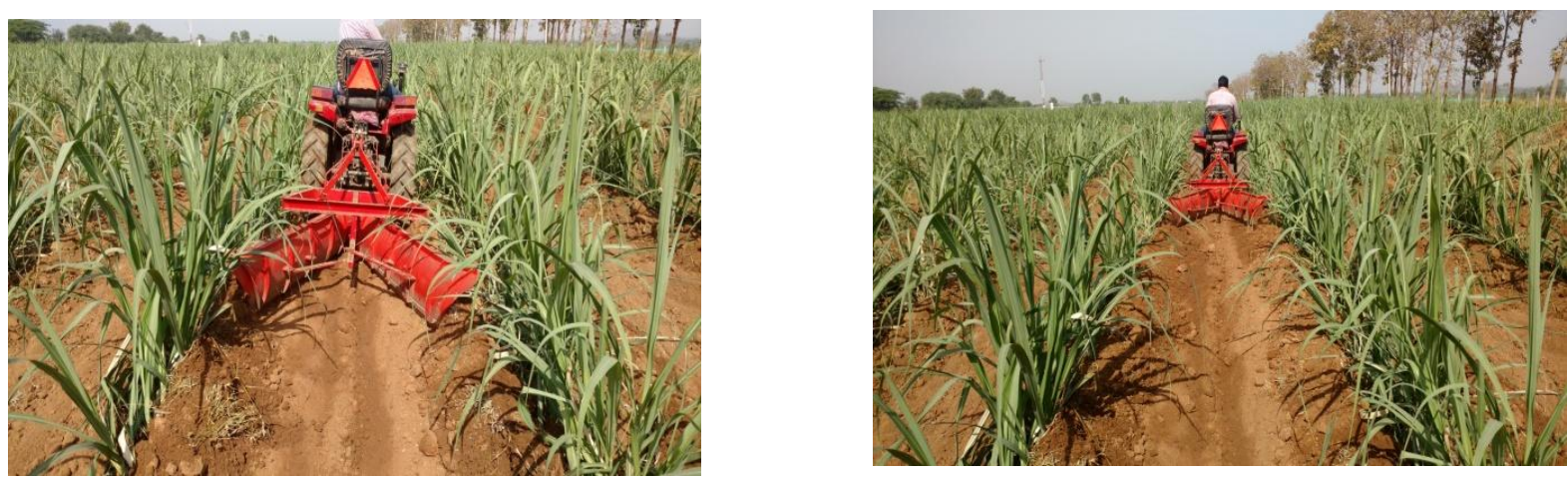


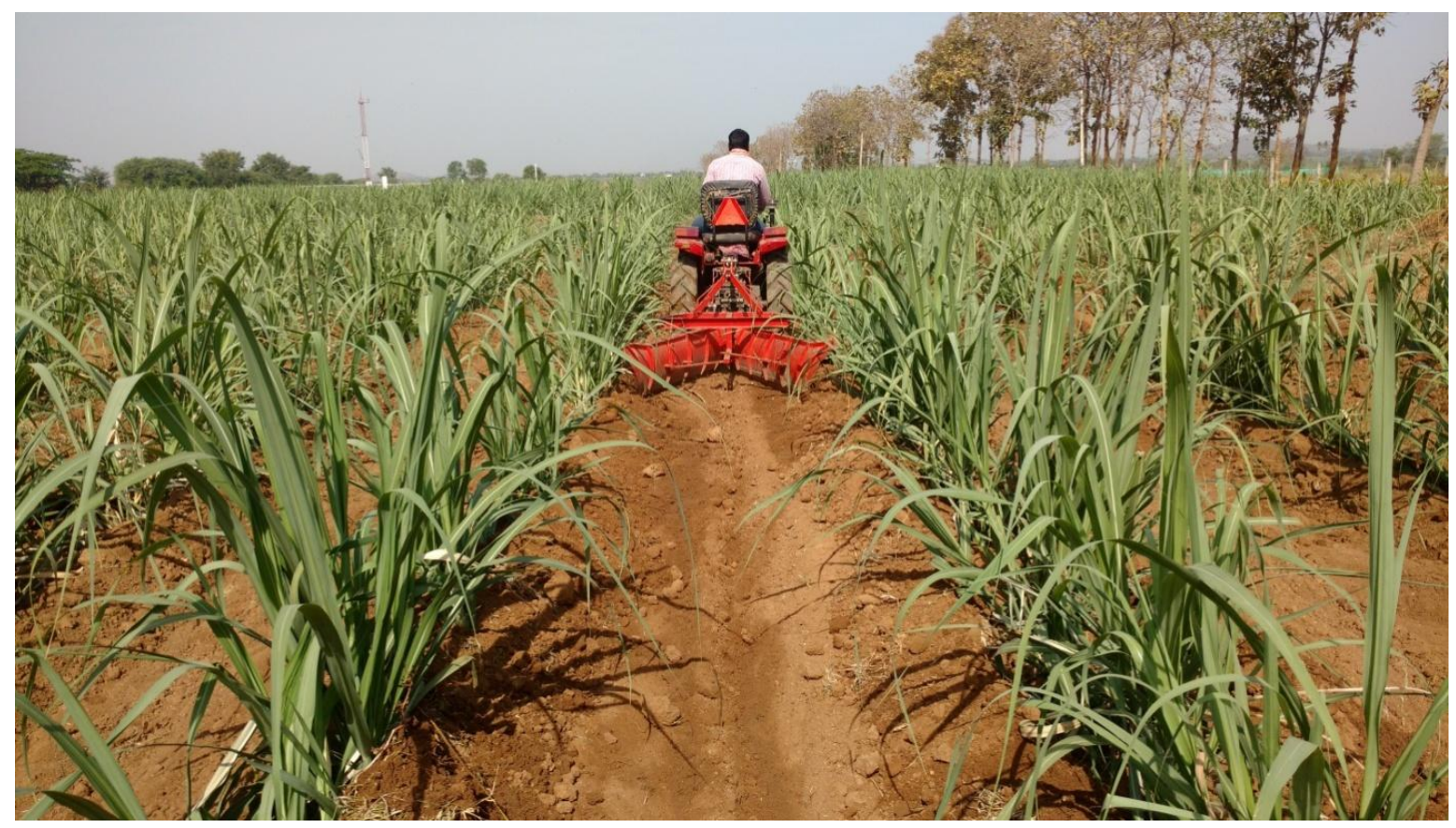

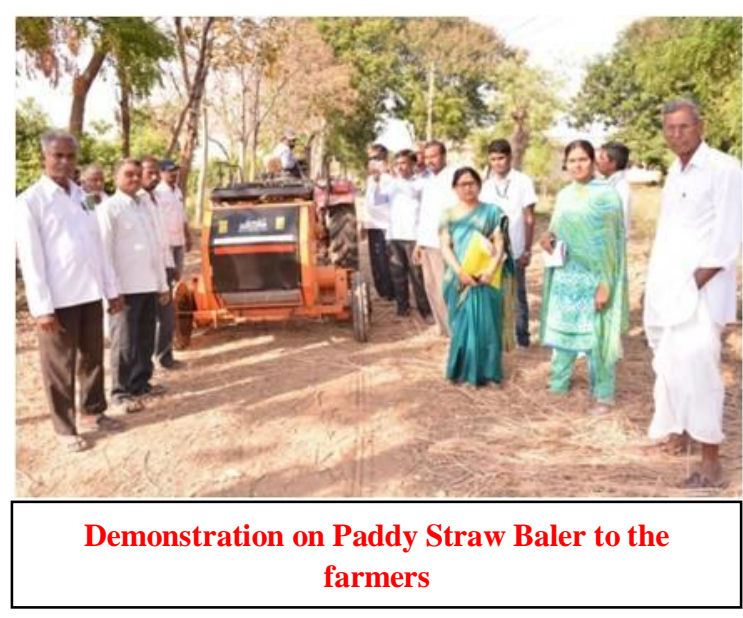

The yield and economic details are depicted in the above table.

\section{Sugarcane Ridger for Earthing Up Operation}

Sugarcane, once a major commercial crop in Nizamabad district with 8132 lakh ha. (During 2011-12) now declined drastically in its cultivable area by 2415 lakh ha due to various reasons. (Source: Directorate of Economics \& Statistics 2015-16) Being high labour intensive crop as one of the major reasons for declined area, a shift is called for

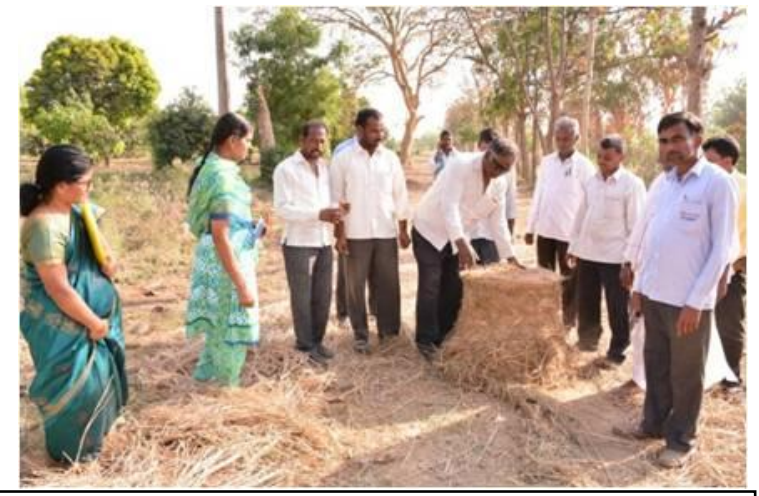

Farmers observing bundle of Paddy Straw Baler

towards mechanization in order to revive its earlier vigour. Hence, the use of Sugarcane Ridger, a tractor drawn implement for whole earthing up operation with slight adjustment in spacing is the need of hour. Sugarcane Ridger allows intercultural operation especially weeding.

In comparision to traditional method of Sugarcane cultivation with less spacing (90 X $30 \mathrm{~cm}$ ), the earthing up operation is laborious requiring 24 labour per day for 2 days per acre with high labour cost incurring more total expenditure. 
Keeping this in view, KVK promoted a tractor drawn Sugarcane Ridger for farm mechanization received under Rashtriya Krishi Vikas Yojana (RKVY) during 2014-15 through Regional Sugarcane \& Rice Research Station (RS\&RRS) by which one could operate 1 acre in a span of 2 hrs performing all the Ridger operations in a single stretch.

Since this ridger performs weeding simultaneously, do not require rotovator thereby suppressing weed growth and increasing yields by $8-10$ per cent. This implement operated with 35.0 HP tractor.

To popularize this, a series of training-cumdemonstration during Kisan Sammelan programmes were organized at the KVK Rudrur. Farmers convinced the performance of the implement which shown a raise in the yields because of well maintenance of micro climate ensuring higher row to row distance $(150.0 \times 30.0 \mathrm{~cm})$ in comparision to the spacing of $90 \mathrm{x} 30 \mathrm{~cm}$ at RS\&RRS experimental plots.

Impressed with the performance in terms of reduced cost of cultivation and higher yields in the RS\&RRS experimental plots, farmers got motivated for the adoption of mechanization in Sugarcane with Sugarcane Ridger.

\section{Baling Bails Out From Pollution}

The practice of burning paddy straw after harvesting is being commonly observed due to high cost involved in traditional method of in-field management. With adoption of latest technologies where combine harvesters replaced the traditional sickle harvesting, huge amount of straw is being burnt away, otherwise could contribute to the income of farmer. Baling is one of the efficient and environmentally safe option against burning practice.
With a view of promoting mechanization in cultivation, strawbaler is one of the implements provided under RKVY scheme by the university to KVK, Rudrur. The baler provided was Shaktiman make and runs with minimum of 35 HP tractor with power drawn from PTO shaft. The baler produces round type bales with size of $2.5 \mathrm{ft}$ width and $2 \mathrm{ft}$ diameter with each bale weighting approximately $10-15 \mathrm{~kg}$ depending on the amount of moisture in the straw with a capacity of 15-18 bales per hour.

The unbaled and non-compacted paddy straw is difficult to transport and takes huge amount of storage space. Demonstrations conducted during the Kisan Sammelans attracted the attention of farmers and realized the advantages of compaction and ability of stalking of bales for easy transport. The straw also fetches additional income to the farmer and saves the expenditure on livestock feed. It also provides rural youth an income generating activity and simultaneously checking the environmental pollution. These advantages impacted many farmers to enquire about the straw baler and few purchased also.

The activities taken up and implements used under RKVY scheme helped the farming community in many folds. The success stories documented on the impact of Distribution of Vanaraja Birds to Miss. Shameem for the promotion of backyard poultry motivated other women to adopt the same. Similarly the success stories documented on the use of Raised bed planter in maize, Sugarcane ridger and Paddy straw baler helped in promoting farm mechanization in Nizamabad district.

\section{Reference}

Rashtriya Krishi Vikas Yojana 2014: Operational guidelines for XII five year plan Department of Agriculture 
and Cooperation, Ministry of Annual Progress reports Krishi Vigyan Agriculture, Government of India. Kendra, Rudrur 2014-15, 2015-16 and Sugarcane crop, Nizamabad. Directorate of $2017-18$

Economics and Statistics 2015-16

\section{How to cite this article:}

Padma Veni C., Bandaru Venkata Rajkumar, P. Vijay Kumar, M. Bhavya Manjari and Kranthi Kumar, B. 2018. Impact of Success Cases under RKVY Scheme at Krishi Vigyan Kendra, Rudrur, Nizamabad District, India. Int.J.Curr.Microbiol.App.Sci. 7(10): 2661-2669. doi: https://doi.org/10.20546/ijcmas.2018.710.309 